\title{
Sex and inflammation in respiratory diseases: a clinical viewpoint
}

\author{
Georges J Casimir ${ }^{1,3^{*}}$, Nicolas Lefèvre ${ }^{1,2}$, Francis Corazza ${ }^{2}$ and Jean Duchateau ${ }^{3}$
}

\begin{abstract}
This review discusses sex differences in the prognosis of acute or chronic inflammatory diseases. The consequences of severe inflammation vary in relation to sex, depending on illness duration. In the majority of acute diseases, males present higher mortality rates, whereas continuous chronic inflammation associated with tissue damage is more deleterious in females. The recruitment of cells, along with its clinical expression, is more significant in females, as reflected by higher inflammatory markers. Given that estrogens or androgens are known to modulate inflammation, their different levels in males and females cannot account for the sexual dimorphism observed in humans and animals from birth to death with regard to inflammation. Numerous studies evaluated receptors, cytokine production, and clinical outcomes in both animals and humans, revealing that estrogens clearly modulate the immune response, but the results are contradictory and difficult to link to hormone concentrations. Even in prepubescent children, the presentation of acute pneumonia or chronic diseases mimics the adult pattern. Several genes located on the $X$ chromosome have been shown to encode molecules involved in inflammation. Moreover, $10 \%$ to $15 \%$ of the genes from silenced $X$ chromosome may escape inhibition. Females are also a mosaic of cells with genes from either paternal or maternal X chromosome. Therefore, polymorphism of X-linked genes would result in the presence of two cell populations with distinct regulatory arsenals, providing females with greater diversity to fight against infectious challenges, in comparison with the uniform cell populations in hemizygous males. The similarities observed between males and Turner syndrome patients using an endotoxin stimulation model support the difference in gene expression between monosomy and disomy for the $\mathrm{X}$ chromosome. Considering the enhanced inflammation in females, cytokine production may be assumed to be higher in females than males. Even if all results are not clear-cut, nonetheless, many studies have reported higher cytokine levels in both male humans and animals than in females. High IL-6 levels in males correlated with poorer prognosis and shorter longevity. A sound understanding of the basic regulatory mechanisms responsible for these gender differences may lead to new therapeutic targets.
\end{abstract}

Keywords: Sex, Respiratory inflammation, X chromosome, Hormones, Cytokines

\section{Review}

\section{Definition of inflammation}

In the majority of cases, inflammation is a defense mechanism of sudden onset that restores homeostatic balance in the case of infection, tumor, and traumatic or ischemic tissue damages. Vascular and exudative processes are predominant with respect to the clinical signs. They are the

\footnotetext{
* Correspondence: georges.casimir@huderf.be

'Department of Pulmonology, Allergology and Cystic Fibrosis, Hôpital Universitaire des Enfants Reine Fabiola, Avenue JJ. Croca 15, B-1020, Brussels, Belgium

${ }^{3}$ Laboratory of Pediatrics, Université Libre de Bruxelles (ULB), Place Arthur Van Gehuchten 4, B-1020, Brussels, Belgium

Full list of author information is available at the end of the article
}

expression of a protective tissue response to injuries, which serves to destroy, dilute, or wall off both the injurious agent and the injured tissues.

Chronic inflammation is less frequent and is mainly observed in cases of prolonged and persistent inflammation predominately marked by new connective tissue formation. It tends to persist for several weeks, months, or years, with a vague and indefinite termination. Chronic inflammation occurs when the injuring agent (or products resulting from its presence) persists in the lesional area, and when the host's tissues respond in a manner (or to a degree) that is insufficient to completely overcome the continuing effects of the injuring agent.

\section{() Biomed Central}


Histopathologically, chronic inflammation is characterized by infiltrates of lymphocytes, plasma cells, histiocytes, and fibrosis. Local deleterious effects are usually observed in the affected tissues leading to permanent organ damages that compromise the disease's prognosis.

At the clinical level, the intensity of inflammation is measured using inflammatory markers, such as C-reactive protein (CRP), erythrocyte sedimentation rate (ESR), or neutrophil count. Higher marker levels are only an indication of the importance of the inflammatory phenomenon.

\section{Expression of biological markers underlying inflammatory processes}

When analyzing these standard inflammatory biological markers, significant differences were observed not only in adults [1] but also between boys and girls younger than 10 years old. Biological parameters increased at the beginning of the inflammatory process and over time, and CRP, ESR, and neutrophil counts reached or exceeded threshold levels, with values being systematically higher in girls than those in boys. However, at the peak inflammatory response, the values observed were rather similar [2]. Neutrophil counts were reported to be higher in females of all ages in several acute inflammatory conditions, such as post-surgical trauma following gastrectomy [3], exerciseinduced muscle injury [4], coronary artery diseases [5], children born to hepatitis C-infected women [6], and even in several basic conditions [7]. Women who subsequently developed cardiovascular events were shown to display higher baseline CRP levels than males of corresponding status [8]. CRP values were also higher in women participating in the Dallas heart study [9]. Females tended to exhibit higher baseline ESR [10], even during childhood [2], which was also observed in pathologic conditions, such as rheumatoid arthritis [11]. The question is, therefore, whether these sex differences in terms of biological markers are associated with clinical differences.

\section{Sexual dimorphism in respiratory diseases along the life course}

During the 1970s, hyaline membrane disease-related mortality was higher in boys than that in girls, with ratios ranging from 1.62 to 1.76 in a published meta-analysis [12]. As regards the meconium aspiration syndrome, male neonates were also more prone to develop the disorder than female neonates [13]. Recent data on 92,332 patients admitted to pediatric hospitals demonstrated a consistent excess of males over females (59\%) for almost all disease categories, with $26 \%$ of diseases relating to the respiratory system. Boys were also more susceptible than girls to acute viral infections, such as bronchiolitis (61\% vs. $53 \%$, $P=0.01$ ) [14]. In a survey involving 7,001 tuberculosis patients from Bangladesh, the female/male ratio was found to be $0.33: 1$ [15]. The tuberculosis case notification rate was reported to be higher for men than that for women worldwide [16]. In 2013, tuberculosis epidemiology is still characterized by significant differences in prevalence rates between men and women worldwide, with cases among men exceeding those found in women with a male/female ratio of 2:1 found in some regions [17]. At any age, boys outnumber girls in acute inflammatory diseases, and their prognosis is worse. Better prognosis in females for acute inflammatory diseases is observed regardless of the age, while worse outcome concerns females of every age with chronic inflammation. Compared to age, the chronicity of the inflammatory process has more adverse effects on girls than on boys by its collateral perverse consequences. When inflammation is not reversible, when the power "ON/OFF" switch of inflammation remains continuously moved to the $\mathrm{ON}$ position, the largest inflammatory mobilization in girls is responsible for deleterious effects. The longer of the inflammation of a tissue lasts, the more damage it does. That could explain the higher mortality in girls suffering from cystic fibrosis or chronic obstructive pulmonary disease (COPD) (Table 1).

In a 2-year prospective study covering a well-defined geographic area of the Spanish Mediterranean coast, the incidence rates of community-acquired pneumonia were higher in males (16 vs. 9 cases per 10,000 people per year, $P<0.0001$ ), in particular among patients aged $>75$ years, with 87 cases per 10,000 people found per year in this patient population [22].

In addition, in animals, there was a male/female bias in relation to induced occurrence, as male mice consistently developed a more severe disease in the lung parenchyma infected by Mycoplasma pulmonis as compared to females [27].

Male gender was reported to be associated with an increased risk of pneumonia and poorer pulmonary prognosis in various clinical conditions, including post-injury and hospitalized community-acquired pneumonia, acute respiratory distress syndrome, HIV-related Pneumocystis carinii pneumonia, current respiratory illness in children, and acute respiratory failure following bone marrow transplantation, along with a higher risk of re-hospitalization $[1,21,23-25,31,36]$. In many acute respiratory diseases, males appear, as they age, to be more susceptible to complications and exhibit a higher mortality [26]. In 1965, an international literature review by Washburn et al. revealed a significant male preponderance for respiratory diseases, especially during infancy [37]. A genetic hypothesis was proposed, suggesting that a gene locus on the $\mathrm{X}$ chromosome in humans was involved in the synthesis of immunoglobulins. The male preponderance and poorer prognosis status were found not only for respiratory diseases but also for most acute inflammatory processes. Several studies from various countries suggested that males, children as well as adults, were more frequently admitted to 
Table 1 Worse prognosis in males in acute diseases and in females during chronic inflammatory diseases

\begin{tabular}{|c|c|c|c|c|}
\hline Disease & Number of patients & Age of patients & Significance & References \\
\hline \multicolumn{5}{|l|}{ Acute diseases (higher in males) } \\
\hline Hyaline membrane disease & 54,064 & Premature newborns & Ratio $1.76: 1$ & {$[12]$} \\
\hline Meconium aspiration & 21,472 & Newborns & $P<0.02$ & [13] \\
\hline Mortality and morbidity of hospitalized children & Nearly 500,000 & Children & $P<0.001$ & {$[18]$} \\
\hline Severe sepsis in children & $1,586,253$ & Children & $P<0.001$ & [19] \\
\hline Pediatric hospital admissions & 92,332 & Children & Males 59\% & [20] \\
\hline Acute respiratory failure after bone marrow transplantation & 318 & Children & $P<0.04$ & [21] \\
\hline Tuberculosis in Bangladesh & 266,189 & Adults & Ratio $M / F, 1: 0.33$ & [15] \\
\hline Tuberculosis in India & 90,000 & Adults & $P<0.05$ & [16] \\
\hline Community-acquired pneumonia & 2-year prospective study & Adults & $P<0.0001$ & [22] \\
\hline Acute respiratory distress syndrome & 333,004 & Adults & $P<0.01$ & [23] \\
\hline Post-injury pneumonia & 30,288 & More than 65 years & $P<0.001$ & [1] \\
\hline Hospitalized community-acquired pneumonia & 623,718 & More than 65 years & $P<0.001$ & [24] \\
\hline In-hospital community-acquired pneumonia (elderly) & 717 & More than 65 years & $P<0.02$ & {$[25]$} \\
\hline Australian seniors with chronic respiratory disease & 108,312 & More than 65 years & $P<0.0003$ & [26] \\
\hline Mycoplasma respiratory disease (mice) & 55 & Adult animals & $P<0.001$ & [27] \\
\hline \multicolumn{5}{|l|}{ Chronic respiratory diseases (poorer prognosis in females) } \\
\hline Chronic inflammatory diseases (children) & 149 children & Children & $P<0.01$ & [28] \\
\hline Asthma in adolescents (sex ratio in severe asthma $5 \mathrm{~F} / 1 \mathrm{M}$ ) & 2,693 & Adolescents & Ratio 1.85:1 & [29] \\
\hline Chronic pulmonary diseases (females smokers) & Meta-analysis $(55,709)$ & Adults & $P<0.008$ & {$[30]$} \\
\hline HIV-related pneumocystis pneumonia & 3,070 & Adults & $P<0.001$ & [31] \\
\hline Cystic fibrosis & 21,047 & 1 to 20 years: females $60 \%$ more likely to die, outside same risk & $P<0.001$ & {$[32]$} \\
\hline Asthma & 3,013 & 5 to 62 years & $P<0.01$ & [33] \\
\hline Chronic obstructive pulmonary diseases (COPD) emergencies & 794 & Adults & $P<0.01$ & [34] \\
\hline COPD & Clinical commentary & Adults & More females than males & [35] \\
\hline
\end{tabular}


intensive care units than females and, thus, more likely to require aggressive life support $[18,38]$. In a recent work on predictors of sequelae and death following bacterial meningitis in childhood, male gender was reported to be a significant prognostic factor, with no satisfactory explanation found [39]. Even in animals, infectious diseases [40] and myocardial infarction [41] were associated with poorer prognosis in males than in females. One possible explanation for this is that inflammatory reactions are likely to be driven by hormonal status. Nonetheless, this prognostic difference was even observed in preterm infants, as documented in several papers $[19,42]$. Clinical data from prepubertal children suggested that potential gene expression differences depended on sex chromosomes rather than hormonal status. Indeed, in these children, hormonal status was largely immature, and sexual hormones were far less abundant, although some studies have shown that in very young children, the mean estrogen levels-still considerably below adult levels-were eight times higher in girls than those in boys [43]. Therefore, in prepubescent children, hormonal differences may still influence the inflammatory response.

\section{Higher inflammatory response in girls}

Although the inflammatory response was reported to be higher in females than in males with acute or chronic respiratory diseases [30], the consequences of severe inflammation varied, depending on the inflammatory process. Females were shown to display a protective advantage in acute conditions, whereas they were more likely to present deleterious tissue damage in relation to continuous chronic inflammation. Gender differences in terms of clinical outcome indicate that during early childhood, chronic inflammatory events underlying the physiological disease mechanism may be more damaging in females than in males. These observations may explain the results of a large American study involving more than 21,000 patients aged 1-20 years that revealed a gender gap in cystic fibrosis mortality [32], with girls exhibiting a $60 \%$ higher mortality risk than boys. This difference could not be accounted for by other risk factors, such as nutritional status, pulmonary function, pathogens in sputum, pancreas insufficiency, or age at diagnosis. In another study relating to asthma [29], severe cases were more frequent in females and more persistent in adulthood, with higher mortality rates after 40 years of age. At any age, severe asthma concerns about $5 \%$ of all asthma cases, but females are almost five times more likely than males to belong to this category, even if there is a male preponderance when considering the whole cohort of asthmatics, with bronchial hyperreactivity shown to be more common in girls, and atopy more common in boys [44]. In addition, new data from a North American population study revealed that males were $46 \%$ less likely to experience asthma exacerbation than females (odds ratio 0.54, 95\% confidence interval 0.31-0.94) [33].

Recently, female gender was associated with poor prognosis of COPD and higher need for post-hospital support [34]. COPD disease expression was found to be different in women and men. In addition to its increased prevalence in females in the case of non-smoker COPD, with patients being more likely to be female, women were more prone to have an airway-predominant (chronic bronchitis) phenotype, and men more likely to develop an emphysema phenotype. This observation was considered to be the consequence of genetic differences in the way males and females manifest damage. Women experienced more severe dyspnea and anxiety, as well as lower disease-related quality of life. Furthermore, when discontinuing treatment with inhaled corticosteroids, women presented a greater likelihood of respiratory deterioration in comparison with men [35]. In a recent paper, we reported that chronic inflammatory diseases in children were more severe in girls than in boys [28]. Our data in the prepubescent children hospitalized for severe exacerbations of chronic asthma supported the hypothesis that inflammation was enhanced in girls, requiring higher corticosteroid doses, longer duration of inhaled therapy, and prolonged hospital stays. In cystic fibrosis as well, inflammation was more marked in females, which was also the case for sickle cell anemia, where we revealed, in line with other authors, that the unexplained poorer prognosis of females was related to a lower forced vital capacity [45].

\section{Hormonal influences}

While estrogens exhibit diverse effects on inflammation and immune responses, the molecular basis of these effects is poorly understood. It is possible that fluctuations in estrogen levels modulate intracellular signaling for immune responses via estrogen receptors. Based on recent a data, 17beta-estradiol was shown to increase, at physiologically high concentrations, the activity of NF-kappa B in human $\mathrm{T}$ cells and induced T cell survival, which may possibly account for the observed gender dimorphism [46]. However, there are other studies showing that estrogens can downregulate the NF-kappa B signaling pathway [47]. A further study revealed that female sex hormones (salutary effects) and male sex steroids (suppressing cardiac and immune functions) were likely to influence the outcome of trauma patients, although the exact mechanisms were not clearly understood [48]. There is still an unresolved paradox with respect to estrogens regarding their immunosupportive role in trauma/sepsis and proinflammatory effects in certain chronic autoimmune diseases in humans. The Straub review reinforced the concept that estrogens exhibit anti-inflammatory and proinflammatory effects, although no uniform concept covering all inflammatory conditions could be found because of the 
highly variable responses of the immune and repair systems [49].

Recent studies focused on the more robust behavioral and somatic responses to stress observed in females, and on the latter's more potent immune and inflammatory reactions [50]. Testosterone has been reported to be inversely associated to the inflammatory process, especially to the levels of markers such as C-reactive protein [51]. Numerous studies evaluated receptors, cytokine production, and clinical outcomes in both animals and humans, revealing that estrogens clearly modulate the immune response. However, these observations were not sufficient to readily explain the universal gender difference observed in acute inflammation, which was found across all age groups, from premature infants to geriatric patients.

\section{Cytokine expression}

In view of the enhanced inflammatory reactions in females, cytokine production may be assumed to be higher in females than in males. Some studies did in fact confirm higher cytokine levels in females, especially in the context of estrogen stimulation [52]. However, other studies reported that IL-6 levels did not change during the menstrual cycle [53]. Although estrogens were shown to be able to slightly modulate cytokine levels, the variations observed were usually not significant or only approached significance when considering stimulations at various periods of the menstrual cycle. In most cases, however, and all along the life course, cytokine concentrations in response to inflammatory stimulation were shown to be higher in males than in females. Estrogen may exhibit pro- and anti-inflammatory properties depending on the context and the involved tissue. Several studies have reported a significantly higher cytokine production in males [54,55], using ex vivo models in humans [56-59] and animals [60-62]. On admission to the emergency department, biomarker patterns in men were characterized by higher levels of tumor necrosis factor, interleukin (IL)-6, and IL10 , which were associated with poorer 1 -year survival rates, as reported by the Genetic and Inflammatory Markers of Sepsis Investigators Group [54]. In a wild-type mice model using intraperitoneally injected endotoxin, males displayed stronger responses than females with respect to myeloid differentiation, myeloid cell release from bone marrow into peripheral blood, and migration into the inflammatory peritoneal cavity, demonstrating that sex differences in inflammatory responses were also observed in animals [55] (Table 2).

In our first in vitro study, we investigated the influence of sex on the production of cytokines involved in inflammation by studying healthy prepubescent males and females, as well as Turner syndrome patients with an $\mathrm{XO}$ genotype (X monosomy) [63]. In this model, despite all Turner syndrome patients being female, there was a male pattern of reactivity, with cytokine production response to endotoxin and pokeweed mitogen (PWM) stimulation of whole blood cells being higher in males than that in females, suggesting a genetic-chromosomal influence. Thus, these findings contrast the numerous clinical observations revealing in vivo increased inflammatory marker production in females. However, in our stimulation model, sex differences in cytokine production depended on the type and intensity of the stimulus $(0.2$ or $1 \mathrm{ng} / \mathrm{ml}$ of endotoxin or PWM), and varied according to the cytokine (IL-1, IL-6 , TNF- $\alpha$, or PGE-2). We observed that, in both males and females, TNF $\alpha$ was highly correlated to IL-6, provided that low doses of lipopolysaccharide or PWM that induced responses in approximately the same relative range were used. A strong correlation between IL- 6 and IL-1 was found, but only in the male group. Given the potential anti-inflammatory effect of IL-6 [64], these relationships may reflect a regulation of both cytokine levels by concomitant IL-6 production. Furthermore, males displayed a significantly lower variation coefficient (slope) than females, suggesting that the influence of IL-6 in reducing IL-1 or TNF $\alpha$ production was more pronounced in males. Caution must be taken, however, as the interindividual variations observed in this study were accounted for by a

Table 2 Biological and clinical features associated to sexual dimorphism in inflammation

\begin{tabular}{|c|c|c|c|}
\hline & Inflammatory mediators & Female & Male \\
\hline \multirow[t]{5}{*}{ Biological markers } & CRP & $\mathbf{T}$ & 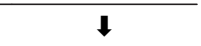 \\
\hline & ESR & $\mathbf{t}$ & $\downarrow$ \\
\hline & IL-8 & $\mathbf{1}$ & $\downarrow$ \\
\hline & IL-1 $\beta, I L-6$, TNF- $a$ & $\downarrow$ & $\mathbf{t}$ \\
\hline & CD99 & $\downarrow$ & $\mathbf{T}$ \\
\hline \multirow[t]{2}{*}{ Hematological markers } & Neutrophil count & $\mathbf{t}$ & $\downarrow$ \\
\hline & Monocyte count & $\downarrow$ & $\mathbf{t}$ \\
\hline \multirow[t]{2}{*}{ Clinical features } & Outcome in acute inflammatory processes (septic shock, burns, trauma) & Better prognosis & Worse prognosis \\
\hline & Outcome in chronic inflammatory processes (severe asthma, cystic fibrosis, BPCO) & Worse prognosis & Better prognosis \\
\hline
\end{tabular}

The table summarizes the main trends observe in the literature. Up arrow denotes increase; down arrow, decrease. 
potential intraindividual modulation inherent to this model, which has not been confirmed to date. Gregory et al. investigated sex differences in cell-mediated immunity in both normal and pathological conditions, following dorsal scald or sham injury in mice [65]. The authors observed differences in both delayed-type hypersensitivity and splenocyte proliferative responses between males and females. These responses were significantly suppressed, with a kinetic profile depending on sex. There was a high expression of IL- 6 at the end of the suppression, while anti-IL-6 antibodies were shown to restore splenocyte proliferation, yet only partially in males but completely in females. This data demonstrates that cell-mediated immunity varies according to sex and that the response to the same inflammatory stimulation differs in males and females, and this is not only in terms of kinetics (quantitatively and qualitatively) but also due to the complex relationships between inflammatory mediators.

In the lungs, complex cytokine networks have been observed, whereby inflammatory cells were shown to regulate fibroblast function, which in turn regulates inflammatory cell function. The effect of an individual cytokine varies according to the activation status of the target cell, presence of other cytokines in the local microenvironment, and ability of the target cell to produce bioactive autacoids, such as prostaglandins [66]. Another study revealed that the inflammatory response, especially to endotoxins, might be predicted by several parameters, such as the promoter polymorphism of the IL-6 gene, sex with males displaying enhanced IL-6 levels as compared to females $(P<0.015)$, density of the endotoxin receptor $\mathrm{CD} 14$, and finally, the concentration of other cytokines. In addition, the IL- 6 response correlated with the concentrations of the more proximal cytokines, namely tumor necrosis factor- $\alpha$ and interleukin-1 $\beta$ [67].

While age may influence the production of cytokines, sex differences remain apparent [68]. Considering the poorer prognosis of males and their higher IL- 6 blood levels, Bonafè et al. investigated 700 subjects aged 60-110 years, including 323 centenarians [69]. The authors showed that the IL-6 promoter genetic variability at the 174 C/G locus and its effect on IL-6 serum levels clearly influenced longevity in homozygous men. The proportion of subjects homozygous for the $G$ allele at the -174 locus decreased in centenarian males, but not in centenarian females. Higher levels of inflammatory markers were predictive of reduced survival time and shorter lifespan among men, whereas only IL- 6 at high levels was associated with longevity in post-menopausal women who did not take estrogens [70].

\section{X-linked genes involved in inflammation}

Several proteins involved in immunity are encoded on the $\mathrm{X}$ chromosome and especially protein members of the toll-like receptor signaling pathway, glucose metabolic enzymes, apoptotic cascade enzymes, or proteins with impact on the hormonal balance. Females carry two $\mathrm{X}$ chromosomes, one of which is randomly inactivated during early embryogenesis in order to maintain the dosage balance of proteins for both sexes [71-73]. Females are, thus, a mosaic of cells with genes from either the paternal or maternal X chromosome. Therefore, polymorphism of $\mathrm{X}$-linked genes would result in the presence of two cell populations with distinct regulatory and functional arsenals, providing females with greater diversity to fight against infectious challenges, in comparison with the uniform cell populations in hemizygous males [74-76]. Moreover, up to $15 \%$ of the $\mathrm{X}$-linked genes escape inactivation to some extent, thereby increasing the X-linked cellular protein content in females compared with that in males $[77,78]$. Some of the main protein members of the toll-like receptor (TLR) and nuclear factor $\kappa B(\mathrm{NF}-\mathrm{kB})$ signaling pathway are linked to the $\mathrm{X}$ chromosome: interleukin 1 receptor Y-associated kinase $1, \mathrm{NF}-\mathrm{kB}$ essential modulator, and Bruton's tyrosine kinase.

Chandra et al. used an animal model to investigate whether female X-chromosome mosaicism for inflammatory gene expression may contribute to the gender dimorphic response during the host response. Using splenic T-cell depletion and post-endotoxin IL-10 responses, the authors showed that the inflammatory response in mosaic animals did not simply display an average of the deficient and wild-type responses, but that the mosaic subjects exhibited a unique characteristic response [79]. In another study, the authors showed that cellular mosaicism for the X-linked gp91phox (NOX2) deficiency, the main subunit of the superoxide anion-generating NADPH oxidase complex, reduced sepsis-induced mortality in deficient mice, as well as in mosaic animals carrying both deficient and WT phagocytes. In mosaic animals, the deficient neutrophils displayed increased organ recruitment and CD11b membrane expression compared with WT neutrophils [80].

In our first in vitro study, the similarities between the male subjects and Turner syndrome patients in terms of the cytokine production pattern support a difference in gene expression between monosomy and disomy for the $\mathrm{X}$ chromosome [63]. More recently, we sought to evaluate the potential role of the $\mathrm{X}$ mosaicism on the expression of the TLR signaling pathway by measuring the production of inflammatory cytokines through the NF- $\mathrm{KB}$ pathway in healthy adults using whole blood stimulated by a gramnegative bacillus endotoxin [81]. In this study, we also observed a higher production of tumor necrosis factor (TNF) $-\alpha$, with a trend towards a higher IL- 6 production, in men. TNF- $\alpha$ production significantly correlated with monocyte counts, with men exhibiting a higher monocyte count than women. One of our hypotheses is that, in males, an early release of high TNF- $\alpha$ and IL- 6 levels by 
monocytes may produce hyperinflammation, thereby contributing to the higher mortality in septic shock observed in males versus females.

In autoimmune diseases [82], immune response genes were shown to be significantly over-represented among genes upregulated in women and among the immune response genes, with the inflammatory/cytotoxic effector genes interferon- $\gamma$, lymphotoxin $\beta$, granzyme $\mathrm{A}$, interleukin-12 receptor $\beta 2$, and granulysin being among those overexpressed to the greatest extent. In contrast, interleukin-17A was the only effector gene found to be more strongly expressed in men.

Another particularity of the $\mathrm{X}$ chromosome, which may be involved in the immune sex dimorphism, is the spreading of the inactivation signal along the pseudoautosomal (PAR1) region of the $\mathrm{X}$ chromosome. The accidental methylation of this region may result in partial silencing of genes lying close to the boundary between the PAR1 region and X-linked material. In our study, the percentage of the monocytes expressing CD99 was higher in men than that in women, thus confirming the higher CD99 expression reported in males using reverse transcription polymerase chain reaction [71]. CD99 is known to play a role in leukocyte diapedesis, and its gene lies closest to the boundary between the PAR1 and X-linked regions. Consequently, a difference in the percentage of monocytes expressing CD99 could affect monocyte recruitment to the inflamed tissues. Increased CD99 expression due to an X; $\mathrm{Y}$ translocation was linked to the early development of a chronic inflammatory disease known to be associated with an imbalanced sex ratio [83]. Some genes implicated in the immune response and located on the X chromosome, such as X-linked genes encoding the proteins of the TLR signaling pathway or genes of the pseudoautosomal PAR1 region such as the CD99 gene, could be responsible for some of the sex-specific responses to inflammation. Therefore, as mosaicism for X-linked polymorphisms may be of clinical relevance, this should be considered in genetic association or sex-related clinical studies.

\section{Conclusions}

The investigation of the inherent biological advantages of healthy normal females may lead to new therapeutic strategies aimed to improve anti-infectious responses in males. Anti-inflammatory drugs exert differing effects on both animals and humans depending on gender [84-86]. Sex may influence the potency of test compounds, such as steroids, or the doses to be used; sex may also determine the phenotype answer to specific drugs. In a 2003 study involving 60,694 Californian asthmatic subjects, females aged 14 to 22 years were found to be more likely outpatients or visit emergency departments and use more oral corticosteroids compared to males [87]. Although females with chronic inflammation used more corticosteroids than males, their prognosis was poorer. Even in animals, chronic inflammation was more significant in females [88]. Accordingly, a better understanding of the inflammatory mechanisms involved in chronic inflammatory processes may be instrumental in decreasing deleterious tissue damage and, thus, be of great benefit for women.

\section{Competing interests}

The authors declare that they have no competing interests.

\section{Authors' contributions}

GJC and JD drafted the manuscript. GJC, FC, JD, and NL participated in the design of the review. GC and JD contributed to the conception of the review. All authors read and approved the final manuscript.

\section{Authors' information}

GJC is a professor of Pediatrics at the Department of Pulmonology and Cystic Fibrosis, Université Libre de Bruxelles (ULB) and the chief medical officer of the University Children Hospital Queen Fabiola, Brussels; FC is the director of the Laboratory of Immunology at the Brugmann University Hospital, Brussels. JD is a professor of Immunology, Laboratory of Pediatrics (ULB). NL is a pediatrician and a doctoral degree student (ULB).

\section{Acknowledgement}

$\mathrm{NL}$ is the recipient of a grant from The Belgian Kid's Fund.

\section{Author details}

${ }^{1}$ Department of Pulmonology, Allergology and Cystic Fibrosis, Hôpital Universitaire des Enfants Reine Fabiola, Avenue JJ. Crocq 15, B-1020, Brussels, Belgium. ${ }^{2}$ Laboratory of Immunology, Hôpital Universitaire Brugmann, Place Arthur Van Gehuchten, 4, B-1020, Brussels, Belgium. ' ${ }^{3}$ aboratory of Pediatrics, Université Libre de Bruxelles (ULB), Place Arthur Van Gehuchten 4, B-1020, Brussels, Belgium.

Received: 25 March 2013 Accepted: 7 August 2013

Published: 1 September 2013

\section{References}

1. Gannon CJ, Pasquale M, Tracy JK, McCarter RJ, Napolitano LM: Male gender is associated with increased risk for postinjury pneumonia. Shock 2004, 21:410-414.

2. Casimir GJA, Mulier S, Hanssens L, Zylberberg K, Duchateau J: Gender differences in inflammatory markers in children. Shock 2010 33:258-262

3. Gwak MS, Choi SJ, Kim JA, Ko JS, Kim TH, Lee SM, Park JA, Kim MH: Effects of gender on white blood cell populations and neutrophil-lymphocyte ratio following gastrectomy in patients with stomach cancer. J Korean Med Sci 2007, 22(Suppl):S104-S108.

4. Maclntyre DL, Reid WD, Lyster DM, McKenzie DC: Different effects of strenuous eccentric exercise on the accumulation of neutrophils in muscle in women and men. Eur J Appl Physiol 2000, 81:47-53.

5. Lindmark E, Wallentin L, Siegbahn A: Blood cell activation, coagulation, and inflammation in men and women with coronary artery disease. Thromb Res 2001, 103:249-259.

6. Pembrey L, Newell M-L, Tovo P-A, European Paediatric Hepatitis C Virus Network: Age-related lymphocyte and neutrophil levels in children of hepatitis C-infected women. Pediatr Infect Dis J 2008, 27:800-807.

7. Bain BJ, England JM: Normal haematological values: sex difference in neutrophil count. Br Med J 1975, 1:306-309.

8. Ridker PM, Buring JE, Shih J, Matias M, Hennekens CH: Prospective study of C-reactive protein and the risk of future cardiovascular events among apparently healthy women. Circulation 1998, 98:731-733.

9. Khera A, McGuire DK, Murphy SA, Stanek HG, Das SR, Vongpatanasin W, Wians FH Jr, Grundy SM, de Lemos JA: Race and gender differences in C-reactive protein levels. J Am Coll Cardiol 2005, 46:464-469.

10. Olshaker JS, Jerrard DA: The erythrocyte sedimentation rate. J Emerg Med 1997, 15:869-874.

11. Radovits BJ, Fransen J, van Riel PLCM, Laan RFJM: Influence of age and gender on the 28-joint Disease Activity Score (DAS28) in rheumatoid arthritis. Ann Rheum Dis 2008, 67:1127-1131 
12. Farrell PM, Wood RE: Epidemiology of hyaline membrane disease in the United States: analysis of national mortality statistics. Pediatrics 1976, 58:167-176.

13. Wiswell TE, Tuggle JM, Turner BS: Meconium aspiration syndrome: have we made a difference? Pediatrics 1990, 85:715-721.

14. Mansbach JM, Emond JA, Camargo CA Jr: Bronchiolitis in US emergency departments 1992 to 2000: epidemiology and practice variation. Pediatr Emerg Care 2005, 21:242-247.

15. Hamid Salim MA, Declercq E, Van Deun A, Saki KAR: Gender differences in tuberculosis: a prevalence survey done in Bangladesh. Int J Tuberc Lung Dis 2004, 8:952-957.

16. Sharma PP, Kumar A, Singh P: A study of gender differentials in the prevalence of tuberculosis based on NFHS-2 and NFHS-3 data. Indian J Community Med 2010, 35:230-237.

17. Rhines AS: The role of sex differences in the prevalence and transmission of tuberculosis. Tuberc Edinb Scot/ 2013, 93:104-107.

18. McCarthy JE, Evans-Gilbert T: Descriptive epidemiology of mortality and morbidity of health-indicator diseases in hospitalized children from western Jamaica. Am J Trop Med Hyg 2009, 80:596-600.

19. Watson RS, Carcillo JA, Linde-Zwirble WT, Clermont G, Lidicker J, Angus DC The epidemiology of severe sepsis in children in the United States. Am J Respir Crit Care Med 2003, 167:695-701.

20. Hon $\mathrm{KL}$, Nelson EA: Sex disparity in paediatric hospital admissions. Ann Acad Med Singapore 2006, 35:882-888.

21. Nichols DG, Walker LK, Wingard JR, Bender KS, Bezman M, Zahurak ML, Piantadosi S, Frey-Simon M, Rogers MC: Predictors of acute respiratory failure after bone marrow transplantation in children. Crit Care Med 1994, 22:1485-1491.

22. Gutiérrez F, Masiá M, Mirete C, Soldán B, Rodríguez JC, Padilla S, Hernández I, Royo G, Martin-Hidalgo A: The influence of age and gender on the population-based incidence of community-acquired pneumonia caused by different microbial pathogens. J Infect 2006, 53:166-174.

23. Moss M, Mannino DM: Race and gender differences in acute respiratory distress syndrome deaths in the United States: an analysis of multiplecause mortality data (1979-1996). Crit Care Med 2002, 30:1679-1685.

24. Kaplan V, Angus DC, Griffin MF, Clermont G, Scott Watson R, Linde-Zwirble WT: Hospitalized community-acquired pneumonia in the elderly: ageand sex-related patterns of care and outcome in the United States. Am J Respir Crit Care Med 2002, 165:766-772.

25. Neupane B, Walter SD, Krueger P, Marrie T, Loeb M: Predictors of inhospital mortality and re-hospitalization in older adults with community-acquired pneumonia: a prospective cohort study. BMC Geriatr 2010, 10:22.

26. Einarsdóttir K, Preen DB, Sanfilippo FM, Reeve R, Emery JD, Holman CDJ: Mortality in Western Australian seniors with chronic respiratory diseases: a cohort study. BMC Public Health 2010, 10:385.

27. Yancey AL, Watson HL, Cartner SC, Simecka JW: Gender is a major factor in determining the severity of mycoplasma respiratory disease in mice. Infect Immun 2001, 69:2865-2871.

28. Casimir GJA, Mulier S, Hanssens L, Knoop C, Ferster A, Hofman B, Duchateau $\mathrm{J}$ : Chronic inflammatory diseases in children are more severe in girls. Shock 2010, 34:23-26.

29. Fagan JK, Scheff PA, Hryhorczuk D, Ramakrishnan V, Ross M, Persky V: Prevalence of asthma and other allergic diseases in an adolescent population: association with gender and race. Ann Allergy Asthma Immunol 2001, 86:177-184.

30. Gan WQ, Man SFP, Postma DS, Camp P, Sin DD: Female smokers beyond the perimenopausal period are at increased risk of chronic obstructive pulmonary disease: a systematic review and meta-analysis. Respir Res 2006, 7:52

31. Bastian L, Bennett CL, Adams J, Waskin H, Divine G, Edlin BR: Differences between men and women with HIV-related Pneumocystis carinii pneumonia: experience from 3,070 cases in New York City in 1987. J Acquir Immune Defic Syndr 1993, 6:617-623.

32. Rosenfeld M, Davis R, FitzSimmons S, Pepe M, Ramsey B: Gender gap in cystic fibrosis mortality. Am J Epidemiol 1997, 145:794-803

33. Smith K, Warholak T, Armstrong E, Leib M, Rehfeld R, Malone D: Evaluation of risk factors and health outcomes among persons with asthma. J Asthma 2009, 46:234-237.

34. Roche N, Zureik M, Soussan D, Neukirch F, Perrotin D, Urgence BPCO (COPD Emergency) Scientific Committee: Predictors of outcomes in COPD exacerbation cases presenting to the emergency department. Eur Respir J 2008, 32:953-961.

35. Han MK, Postma D, Mannino DM, Giardino ND, Buist S, Curtis JL, Martinez FJ: Gender and chronic obstructive pulmonary disease: why it matters. Am J Respir Crit Care Med 2007, 176:1179-1184

36. Gold DR, Rotnitzky A, Damokosh Al, Ware JH, Speizer FE, Ferris BG Jr Dockery DW: Race and gender differences in respiratory illness prevalence and their relationship to environmental exposures in children 7 to 14 years of age. Am Rev Respir Dis 1993, 148:10-18.

37. Washburn TC, Medearis DN Jr, Childs B: Sex differences in susceptibility to infections. Pediatrics 1965, 35:57-64.

38. Fowler RA, Filate W, Hartleib M, Frost DW, Lazongas C, Hladunewich M: Sex and critical illness. Curr Opin Crit Care 2009, 15:442-449.

39. De Jonge RCJ, van Furth AM, Wassenaar M, Gemke RJBJ, Terwee CB: Predicting sequelae and death after bacterial meningitis in childhood: a systematic review of prognostic studies. BMC Infect Dis 2010, 10:232.

40. Butcher AR, Palethorpe HM, Grove DI: Effects of sex and age on the susceptibility of $\mathrm{C} 57 \mathrm{BL} / 6 \mathrm{~J}$ mice to infection with Brachylaima cribbi and the course of infection in NOD SCID mice. Parasitol Res 2002, 88:668-674.

41. Cavasin MA, Tao Z, Menon S, Yang X-P: Gender differences in cardiac function during early remodeling after acute myocardial infarction in mice. Life Sci 2004, 75:2181-2192

42. McGregor JA, Leff $M$, Orleans $M$, Baron A: Fetal gender differences in preterm birth: findings in a North American cohort. Am J Perinatol 1992, 9:43-48.

43. Klein KO, Baron J, Colli MJ, McDonnell DP, Cutler GB Jr: Estrogen levels in childhood determined by an ultrasensitive recombinant cell bioassay. J Clin Invest 1994, 94:2475-2480.

44. Collins RA, Parsons F, Deverell M, Hollams EM, Holt PG, Sly PD: Risk factors for bronchial hyperresponsiveness in teenagers differ with sex and atopic status. J Allergy Clin Immunol 2011, 128:301-307. e1.

45. Field JJ, DeBaun MR, Yan Y, Strunk RC: Growth of lung function in children with sickle cell anemia. Pediatr Pulmonol 2008, 43:1061-1066.

46. Hirano S, Furutama D, Hanafusa T: Physiologically high concentrations of 17beta-estradiol enhance NF-kappaB activity in human T cells. Am J Physiol Regul Integr Comp Physiol 2007, 292:R1465-R1471.

47. Guzeloglu-Kayisli O, Halis G, Taskiran S, Kayisli UA, Arici A: DNA-binding ability of NF-kappaB is affected differently by ERalpha and ERbeta and its activation results in inhibition of estrogen responsiveness. Reprod $\mathrm{SCi}$ 2008, 15:493-505.

48. Choudhry MA, Bland Kl, Chaudry $\mathrm{H}$ : Gender and susceptibility to sepsis following trauma. Endocr Metab Immune Disord Drug Targets 2006, 6:127-135

49. Straub RH: The complex role of estrogens in inflammation. Endocr Rev 2007, 28:521-574

50. Chrousos GP: Stress and sex versus immunity and inflammation. Sci Signal 2010, 3:pe36.

51. Zhang Y, Gao Y, Tan A, Yang X, Zhang H, Zhang S, Wu C, Lu Z, Wang M, Liao M, Qin X, Li L, Hu Y, Mo Z: Endogenous sex hormones and C-reactive protein in healthy Chinese men. Clin Endocrinol (Oxf) 2013, 78:60-66.

52. Jenkins DJA, Kendall CWC, Connelly PW, Jackson C-JC, Parker T, Faulkner D, Vidgen E: Effects of high- and low-isoflavone (phytoestrogen) soy foods on inflammatory biomarkers and proinflammatory cytokines in middleaged men and women. Metabolism 2002, 51:919-924.

53. Chaffin ME, Berg KE, Meendering JR, Llewellyn TL, French JA, Davis JE: Interleukin-6 and delayed onset muscle soreness do not vary during the menstrual cycle. Res Q Exerc Sport 2011, 82:693-701.

54. Roberts BJ, Dragon JA, Moussawi M, Huber SA: Sex-specific signaling through Toll-like receptors 2 and 4 contributes to survival outcome of Coxsackievirus B3 infection in C57BI/6 mice. Biol Sex Differ 2012, 3:25.

55. Aoyama M, Kotani J, Usami M: Gender difference in granulocyte dynamics and apoptosis and the role of IL-18 during endotoxin-induced systemic inflammation. Shock 2009, 32:401-409.

56. Moxley G, Posthuma D, Carlson P, Estrada E, Han J, Benson LL, Neale MC Sexual dimorphism in innate immunity. Arthritis Rheum 2002, 46:250-258.

57. Moxley G, Stern AG, Carlson P, Estrada E, Han J, Benson LL: Premenopausal sexual dimorphism in lipopolysaccharide-stimulated production and secretion of tumor necrosis factor. J Rheumatol 2004, 31:686-694.

58. Imahara SD, Jelacic S, Junker CE, O'Keefe GE: The influence of gender on human innate immunity. Surgery 2005, 138:275-282. 
59. Bauer I, Bauer M, Raddatz A, Luedtke C, Werth M, Silomon M, Rensing H, Wilhelm W: Influence of gender on stimulated cytokine response in patients with severe sepsis. Anaesthesist 2006, 55:515-527.

60. Marriott I, Bost KL, Huet-Hudson YM: Sexual dimorphism in expression of receptors for bacterial lipopolysaccharides in murine macrophages: a possible mechanism for gender-based differences in endotoxic shock susceptibility. J Reprod Immunol 2006, 71:12-27.

61. Eisenmenger SJ, Wichmann MW, Angele P, Faist E, Hatz R, Chaudry $\mid H$, Jauch KW, Angele MK: Differences in the expression of LPS-receptors are not responsible for the sex-specific immune response after trauma and hemorrhagic shock. Cell Immunol 2004, 230:17-22

62. Tyagi P, Tyagi V, Yoshimura N, Witteemer E, Barclay D, Loughran PA, Zamora $R$, Vodovotz Y: Gender-based reciprocal expression of transforming growth factor-beta 1 and the inducible nitric oxide synthase in a rat model of cyclophosphamide-induced cystitis. J Inflamm (Lond) 2009, 6:23.

63. Casimir GJ, Heldenbergh F, Hanssens L, Mulier S, Heinrichs C, Lefevre N, Désir J, Corazza F, Duchateau J: Gender differences and inflammation: an in vitro model of blood cells stimulation in prepubescent children. J Inflamm (Lond) 2010, 7:28

64. Heinrich PC, Castell JV, Andus T: Interleukin-6 and the acute phase response. Biochem J 1990, 265:621-636.

65. Gregory MS, Faunce DE, Duffner LA, Kovacs EJ: Gender difference in cellmediated immunity after thermal injury is mediated, in part, by elevated levels of interleukin-6. J Leukoc Biol 2000, 67:319-326.

66. Elias JA, Freundlich B, Kern JA, Rosenbloom J: Cytokine networks in the regulation of inflammation and fibrosis in the lung. Chest 1990, 97:1439-1445.

67. Heesen M, Bloemeke B, Heussen N, Kunz D: Can the interleukin-6 response to endotoxin be predicted? Studies of the influence of a promoter polymorphism of the interleukin- 6 gene, gender, the density of the endotoxin receptor CD14, and inflammatory cytokines. Crit Care Med 2002, 30:664-669.

68. Pietschmann P, Gollob E, Brosch S, Hahn P, Kudlacek S, Willheim M, Woloszczuk W, Peterlik M, Tragl KH: The effect of age and gender on cytokine production by human peripheral blood mononuclear cells and markers of bone metabolism. Exp Gerontol 2003, 38:1119-1127.

69. Bonafè M, Olivieri F, Cavallone L, Giovagnetti S, Mayegiani F, Cardelli M, Pieri C, Marra M, Antonicelli R, Lisa R, Rizzo MR, Paolisso G, Monti D, Franceschi C: A gender-dependent genetic predisposition to produce high levels of IL6 is detrimental for longevity. Eur J Immunol 2001, 31:2357-2361.

70. Wassel CL, Barrett-Connor E, Laughlin GA: Association of circulating Creactive protein and interleukin- 6 with longevity into the $80 \mathrm{~s}$ and $90 \mathrm{~s}$ : The Rancho Bernardo Study. J Clin Endocrinol Metab 2010, 95:4748-4755.

71. Johnston CM, Lovell FL, Leongamornlert DA, Stranger BE, Dermitzakis ET, Ross MT: Large-scale population study of human cell lines indicates that dosage compensation is virtually complete. Plos Genet 2008, 4:e9.

72. Dementyeva EV, Shevchenko Al, Zakian SM: X-chromosome upregulation and inactivation: two sides of the dosage compensation mechanism in mammals. Bioessays 2009, 31:21-28.

73. Prothero KE, Stahl JM, Carrel L: Dosage compensation and gene expression on the mammalian $\mathrm{X}$ chromosome: one plus one does not always equal two. Chromosome Res 2009, 17:637-648.

74. Migeon BR: The role of $X$ inactivation and cellular mosaicism in women's health and sex-specific diseases. JAMA 2006, 295:1428-1433.

75. Migeon BR: Why females are mosaics, X-chromosome inactivation, and sex differences in disease. Gend Med 2007, 4:97-105.

76. Spolarics Z: The X-files of inflammation: cellular mosaicism of X-linked polymorphic genes and the female advantage in the host response to injury and infection. Shock 2007, 27:597-604.

77. Carrel L, Willard HF: X-inactivation profile reveals extensive variability in X-linked gene expression in females. Nature 2005, 434:400-404.

78. Ozcelik T: $X$ chromosome inactivation and female predisposition to autoimmunity. Clin Rev Allergy Immunol 2008, 34:348-351.

79. Chandra R, Federici S, Haskó G, Deitch EA, Spolarics Z: Female Xchromosome mosaicism for gp91phox expression diversifies leukocyte responses during endotoxemia. Crit Care Med 2010, 38:2003-2010.

80. Chandra R, Federici S, Németh ZH, Horváth B, Pacher P, Haskó G, Deitch EA, Spolarics Z: Female X-chromosome mosaicism for NOX2 deficiency presents unique inflammatory phenotype and improves outcome in polymicrobial sepsis. J Immunol 2011, 186:6465-6473.
81. Lefèvre N, Corazza F, Duchateau J, Desir J, Casimir G: Sex differences in inflammatory cytokines and CD99 expression following in vitro lipopolysaccharide stimulation. Shock 2012, 38:37-42.

82. Hewagama A, Patel D, Yarlagadda S, Strickland FM, Richardson BC: Stronger inflammatory/cytotoxic T-cell response in women identified by microarray analysis. Genes Immun 2009, 10:509-516.

83. Chagnon P, Schneider R, Hébert J, Fortin PR, Provost S, Belisle C, Gingras M, Bolduc V, Perreault C, Silverman E, Busque L: Identification and characterization of an Xp22.33;Yp11.2 translocation causing a triplication of several genes of the pseudoautosomal region 1 in an XX male patient with severe systemic lupus erythematosus. Arthritis Rheum 2006, 54:1270-1278

84. Romero R, Gotsch F, Pineles B, Kusanovic JP: Inflammation in pregnancy: its roles in reproductive physiology, obstetrical complications, and fetal injury. Nutr Rev 2007, 65(12 Pt 2):S194-S202.

85. Chillingworth NL, Morham SG, Donaldson LF: Sex differences in inflammation and inflammatory pain in cyclooxygenase-deficient mice. Am J Physiol Regul Integr Comp Physiol 2006, 291:R327-R334.

86. Corteling R, Trifilieff A: Gender comparison in a murine model of allergendriven airway inflammation and the response to budesonide treatment. BMC Pharmacol 2004, 4:4.

87. Schatz M, Camargo CA Jr: The relationship of sex to asthma prevalence, health care utilization, and medications in a large managed care organization. Ann Allergy Asthma Immunol 2003, 91:553-558.

88. Scotland RS, Stables MJ, Madalli S, Watson P, Gilroy DW: Sex differences in resident immune cell phenotype underlie more efficient acute inflammatory responses in female mice. Blood 2011, 118:5918-5927.

doi:10.1186/2042-6410-4-16

Cite this article as: Casimir et al: Sex and inflammation in respiratory diseases: a clinical viewpoint. Biology of Sex Differences 2013 4:16.

\section{Submit your next manuscript to BioMed Central and take full advantage of:}

- Convenient online submission

- Thorough peer review

- No space constraints or color figure charges

- Immediate publication on acceptance

- Inclusion in PubMed, CAS, Scopus and Google Scholar

- Research which is freely available for redistribution 